Israeli research

\section{Neglecting the basics}

Rehovot

ISRAELI basic research has dropped to "a dangerously low level" according to Professor Haim Harari, who heads the planning and grants committee of Israel's Council for Higher Education. Speaking at the recent Bat-Sheva de Rothschild seminar on science policy, Harari argued that in the past ten years Israel has gone from an over-emphasis on basic research to neglect.

This shift stems from the financial plight of Israeli universities, which now have to make do with a total annual budget of $\$ 400$ million, roughly what a single American university, Stanford (with its medical school and accelerator), spends annually. Some 70 per cent of the Israeli university budget comes from government, but how the government's share is distributed depends solely on members of the planning and grants committee, who, once appointed by the Minister of Education, are free to allocate funds as they see fit.

The government does decide, however, on the total size of its financial commitment, which has not kept pace with the growth of universities and with rising costs. As a result, local institutions of higher education must spend almost all their available funds on salaries and maintenance, leaving little for such "luxuries" as basic research.

There is a great deal of money from government ministries and booming science-based industries for applied research, but neither will support basic research, with the result, Harari says, that many professors who lean in that direction are "unemployed". To be sure, they still have their salaries, but they have no funds for equipment, technicians and the like.

Admittedly influenced by the fact that he is a theoretical physicist interested in elementary particle physics, what he terms "perhaps the most basic research", Harari is alarmed by the trend away from basic

Australian-USSR relations \section{Sanctions lifted}

\section{Canberra}

As anticipated, the federal government last week lifted all sanctions against the Soviet Union originally imposed after the intervention in Afghanistan (see Nature 21 April, p.648). Cultural, sporting, scientific and academic exchanges can now be resumed. The Minister for Foreign Affairs, Mr Bill Hayden, said that the decision had been taken "in the wider interests of involving the Soviet Union in a more productive relationship". The move will no doubt make reparation for the expulsion in April of a first secretary at the Soviet Embassy, Mr Valeriy Ivanov, alleged to be aspy. research. So he and his colleagues on the planning and grants committee have decided to "confiscate" three per cent of the money allocated for higher education and to set it aside for basic research. They hope that this will rise to five per cent in the years ahead.

Professor Harari points out that Israel's booming computer-related companies are an outgrowth of computer research at the Weizmann Institute in the 1950s and 1960s, while Israel's aircraft industry could not have been developed if the faculty of aeronautical engineering had not been established at the Haifa Technion long before there was thought of such an industry.

But "today's basic research", Professor Harari warns, "does not provide the basis for economic advances in the year 2000". Participants in the seminar also heard a spirited defence of basic research from the Minister of Science and Development, Professor Yuval Ne'eman, who, like Professor Harari, is a physicist.

Although he actually has access to less money than Harari (the science ministry's total budget this year is only $\$ 9$ million), Professor Ne'eman intends to do all he can to ensure that some Israeli scientists are able to do basic research or, as he puts it, "to grope in the dark".

There were no complaints about the present situation from those at the seminar who are primarily connected with applied research and science-based industry, among them the Chief Scientist at the Ministry of Industry and Commerce, Professor Arie Lavie, and the head of the Elron electronics company, Mr Uzia Galil.

Professor Lavie reported that large-scale Israeli Government support for research projects linked to science-based industry had been very successful, with some 50 per cent of them ending with saleable products, more than $\$ 1,000$ million of which were ex ported last year. Moreover, he reported, bilateral applied research projects had long been supported by the US Government and new agreements meant that such support would also be forthcoming from Canada and France. But by far the most important source of research funds was provided by stock sales. In just one month, Professor Lavie said, three Israeli science-based industries had raised $\$ 100$ million on the New York Stock Exchange, and another three expect to raise $\$ 50$ million more in the immediate future.

According to Uzia Galil, the money is available for investment in good sciencebased projects but there are not enough good projects to go round. A lot of new ones, he predicted, will be initiated by expatriate Israelis who, having developed electronics and computer companies in the United States, are now anxious to do the same thing in the land of their birth.

Nechemia Meyers
Polish pollution

\section{Changes may come at last}

POLAND's Council of Ministers last month bent to the need for a government agency dealing with the environment. It adopted a draft resolution breaking up the Ministry of Administration, Local Economy and Environmental Protection and establishing a Main Office for Environmental Protection and Water Resource Management.

The need for a separate body has been apparent for some time, in spite of censorship during the 1970s on all environmental issues. By making the new body a main office and not a ministry, the Council of Ministers has tacitly accepted the urgency of the problem - as a main office, the new body will be answerable to the Prime Minister.

The proposed new body will face the three endemic problems of all Polish planners: lack of resources, lack of verified data and lack of public confidence. Until 1980, little was published generally about environmental pollution. Although partial statistics were available to experts and officials, the residents of the major industrial conurbations, especially Silesia and the Krakow area, found themselves having to cope with the qualitative aspects of the problem without objective data on the hazards. (It was widely believed, for example, that vegetables grown too near the Nowa Huta steel mills were a health risk because of dust from the scrap-metal recycling plant.) In some cases the underground press reported on major health hazards, in particular the sewage pollution of the Bay of Gdansk, but these "independent" commentators may often have underestimated the hazards.

During the comparatively open Solidarity period, the Krakow-based Polish Ecological Club was instrumental in January 1981 in having banned one of the main sources of pollution, hydrogen fluoride from the obsolete smelting shops at the Skawina aluminium works which had been emitting hydrogen fluoride in quantities sufficient to corrode gold art treasures in Krakow's Wawel Castle museum.

This openness has, to a certain extent, continued under martial law, gradually building up a picture of ecological neardisaster, with rivers, lakes, coastal waters, soil, forests and residential areas all at risk. But funds to rectify matters have been scarce - and, as the presidium of the Central Committee's Commission for Health and Environmental Protection noted last November, there remain "considerable discrepancies" between the of ficial reports on remedial measures and the perceptions of the local population.

Indeed, as Politburo member Zofia Grzyb told that meeting, the shortage of resources would make it impossible to realize many recommended measures in the 